\title{
The Ill(s) of the Nation: The Experience of Tuberculosis in Finland from the 1920s to the 1970s
}

\author{
Heini Hakosalo
}

\section{INTRODUCTION}

This chapter focuses on narrated experiences of tuberculosis. The investigation is based on and made possible by a major collection of written tuberculosis-related recollections called the Collection Competition for Sanatorium Tradition (ST). The collection was organized in 1971 by the Finnish Literature Society and the Chest Patients' Union on the occasion of the latter's 30th anniversary. Circa 350 people answered the writing call, mailing in over 9000 pages of written reminiscences and over 1000 photographs. ${ }^{1}$ The bulk of ST contributions can be characterized as illness

\footnotetext{
${ }^{1}$ The collection is held by the Finnish Literature Society Archives (FLSA, Archive Materials on Literature and Cultural History) in Helsinki. The material is organized alphabetically, by the surname of the author. I will refer to individual contributions by the author's surname. An exception to this rule is a bulk of written recollections and transcribed inter-
}

\footnotetext{
H. Hakosalo $(\bowtie)$

University of Oulu, Oulu, Finland

e-mail: heini.hakosalo@oulu.fi
}

(C) The Author(s) 2021

V. Kivimäki et al. (eds.), Lived Nation as the History of Experiences

and Emotions in Finland, 1800-2000, Palgrave Studies in the

History of Experience,

https://doi.org/10.1007/978-3-030-69882-9_10 
narratives. They unfold over time, have a beginning and an end, and one or more recognizable protagonists. ${ }^{2}$ Although they focus on tuberculosis, they often deal more broadly with the protagonists' lives and other illnesses, growing into veritable pathographies. As I see it, an essential feature and a key function of an illness narrative is to assign meaning to suffering. I argue that one way for ST narrators to make sense of their dire, often traumatic, illness histories was to place them into the context of national history. In this chapter, I will discuss three narrative strands that figure prominently in the material and that allowed the authors to assimilate their personal illnesses with the collective ills of the nation: (1) stories of progress, (2) stories of war, and (3) stories of belonging.

As discussed in the Introduction, thematic writing calls have been and still are popular in Finland. They have been carried out by folklore studies departments and by major national memory institutions, like the National Board of Antiquities, the Finnish Literature Society and its Swedishspeaking counterpart, the Society for Swedish Literature in Finland. The original purpose of these "heritage" or "folklore" collections was to document deep-rooted collective traditions, especially peasant traditions that were thought to be threatened by modernization. The preferred informants were rural common people. A shift of emphasis took place in the 1960s: while the calls remained popular, they were increasingly likely to target urban and educated sections of the population, focus on themes with no direct connection to the traditional rural way of life, and to encourage people to reflect upon their own views and feelings rather than just document collective beliefs and practices. ${ }^{3}$ Heritage collections have been carried out in the other Nordic and in the Baltic countries as well. ${ }^{4}$ However, from the point of view of the international historiography of

views that were amassed by active members of the Chest Patients' Union and filed collectively under the name "Chest Patients' Union Material" (henceforth CPUM). Three authors have requested that their real names not be used. I will refer to them by a pseudonym, put in inverted commas.

${ }^{2}$ Illness narratives have interested medical anthropologists and literary scholars more than they have historians. A seminal anthropological study on illness narratives is Arthur W. Frank, The Wounded Storyteller: Body, Illness \& Ethics, 2nd ed. (Chicago: University of Chicago Press, 2013 [1995]), 77-80, 83.

${ }^{3}$ On the history of heritage collections, see Kirjoittamalla kerrotut: Kansatieteelliset kyselyt tiedon lähteinä, ed. by Pirjo Korkiakangas et al. (Helsinki: Ethnos, 2016) and Kansanrunousarkisto, lukijat ja tulkinnat, ed. Tuulikki Kurki (Helsinki: SKS, 2004).

${ }^{4}$ Anne Heimo, "Nordic-Baltic Oral History of the Move," Oral History 44:2 (2016), 37-46. 
tuberculosis, Sanatorium Tradition constitutes a rare, if not a unique resource.

Although the materials accumulated in the various Finnish heritage collections have primarily been employed by folklore scholars, they also have considerable historiographical value. The practice itself is interesting from the point of view of the overarching theme of this volume. Given that heritage collections were carried out by eminent national organizations, addressed to "the people," and open to anyone who felt she had anything to contribute, it is possible to see heritage collections as a form of citizen science-or rather citizen scholarship - and as an opportunity afforded by state institutions for ordinary people to contribute to national history. Sanatorium Tradition represents "history from below" in two respects. First, the majority of the contributions can be regarded as histories, as they assume a chronological, narrative form and seek to identify significant changes. Second, they offer a view from below, as the authors mainly belonged to "the common folk." Members of the elite did not contribute, and upper middle-class, academically educated people, as well as the Swedish-speaking minority, are clearly underrepresented, even when we take into account the socially selective nature of the disease. Gender-wise, the collection is relatively well balanced: although female participants are more numerous, men wrote, on average, more. ${ }^{5}$

$S T$ contributions are highly varied. They differ in length, style, perspective, and tone, reflecting differences in the authors' ages, genders, education, social backgrounds, and disease histories. ${ }^{6}$ Most are autobiographical

${ }^{5}$ The background materials related to the collection-the organizers' correspondence, summaries, and newspaper clippings — can be found in a separate case at FLSA (no signum). $S T$, or parts of it, has previously been used as source material by the folklore scholar Aili Nenola, by myself, and also in at least three unpublished masters' theses. Aili Nenola, Parantolaelämää - tuberkuloosipotilaat muistelevat (Helsinki: Keuhkovammaliitto, 1986); Heini Hakosalo, “The Woodland Cure: Tuberculosis Sanatoria and Patients' Perceptions of the Healing Power of Nature," in In Pursuit of Healthy Environments: Lessons from Historical Cases on the Environment-Health Nexus, ed. by Esa Ruuskanen and Heini Hakosalo (London: Routledge, 2021); Heini Hakosalo, "Tubipommi ja rautlasi: Emotionaalisia esineitä 1900luvun alkupuolen suomalaisissa tuberkuloosiparantoloissa," Historiallinen Aikakauskirja $114: 2$ (2016), 165-76.

${ }^{6}$ The variability of experiences of tuberculosis has also been emphasized, e.g., by Stacie Burke, Building Resistance: Children, Tuberculosis and the Toronto Sanatorium (Montreal: McGill-Queen's University Press, 2018), 262; Anne Shaw \& Carole Reeves, The Children of Craig-y-nos: Life in a Welsh Tuberculosis Sanatorium, 1922-1959 (Milton Keynes: Wellcome Trust Centre, 2009). 
accounts written specifically as an answer to the call in 1971, but the collection also includes second-hand texts recounting other peoples' experiences, printed materials such as newspaper clippings, and contemporary textual remnants such as excerpts from diaries, letters, and sanatorium magazines. Some authors focused on recording outward circumstances and events, others on their personal experiences. The participants were free to assume whatever authorial position they wanted, and while some clearly saw themselves as folklore informants, others wrote more like historians, autobiographers, diarists, or authors. The authorial position could also shift within one and the same contribution. ${ }^{7}$ To quote the oral historian Alessandro Portelli, the participants were free to move between "subject-oriented life-story and theme-oriented testimony." 8

The concept of experience that informs this chapter is summed up in Fig. 10.1. As I see it, historical study of experience is concerned with the ways in which people have made sense of their emotions by means of culturally available conceptual tools. Experiences are thought emotions. They are conceptualized and intentional, that is, they are about something. They are also perspectival: they are someone's thought emotions, and to speak about "my experience" or "their experiences" is to recognize them as restricted reconstructions of the world from a specific point of view. The definition brings together, first, the emotional and the cognitive and, second, the individual and the collective. Although we often study experiences through the utterances of individuals, it is clear that what people think and feel is dependent on the ways that the communities to which they belong think and feel. It is also obvious that experience thus defined is a historical and cultural phenomenon, that is, that it varies over time and from one culture to another. ${ }^{9}$ Experiences do not necessarily have to be

\footnotetext{
${ }^{7}$ Such shifts in the authorial position make it difficult to decide what to call the authors. I do not want, at least not consistently, to call them patients. "Patient" is a relational term, and most of the narrators would not have identified themselves as patients at the time of writing, nor did they always do so even when they were ill. I call them patients when they are writing from a patient position, i.e., as sanatorium patients or in relation to a healthcare professional, but otherwise use other denominations such as authors, narrators, or participants.

${ }^{8}$ Alessandro Portelli, The Battle of Valle Giulia: Oral History and the Art of Dialogue (Madison, Wisconsin: University of Wisconsin Press, 1997), 6.

${ }^{9}$ The notion of experience comes with a huge theoretical and methodological package, having been theorized and debated in philosophy, psychology, and other fields of science and scholarship for decades, perhaps for centuries. It is clearly not possible to provide anything like a comprehensive discussion within the constraints of this chapter. I assume that the most controversial part of my short instrumental definition of experiences as "thought emotions"
} 
EMOTIONAL COGNITIVE

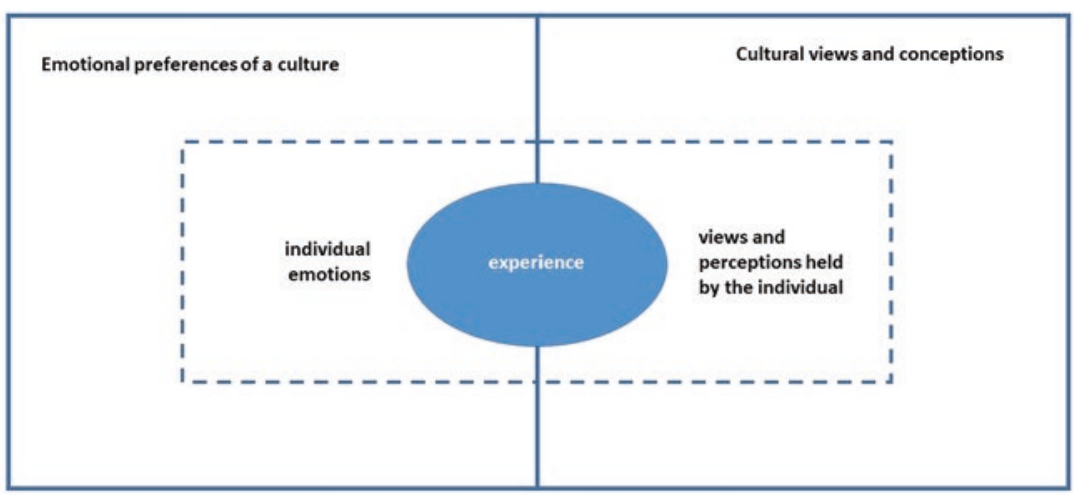

Fig. 10.1 The dimensions of historical study of experience

narrative in form, ${ }^{10}$ although historical studies of experience do show a strong preference for the use of narrative material.

Historical research on tuberculosis is plentiful, particularly for the period between 1880 and 1960. While the historiographical emphasis has been on tuberculosis as a public health issue and a medical problem, the patient's view has not been neglected. ${ }^{11}$ However, I believe that this

is the way it prioritizes emotions. This order of priorities is based on the simple observation that while it is possible to conduct a historical study on a concept without including the emotions of the people who have devised or employed the concept, it is impossible to conduct a historical study on non-conceptualized emotions (that some would call affects or arousalstage emotions). Broadly speaking, the definition is inspired by the social constructionist view on emotions. See, e.g., Barbara H. Rosenwein \& Riccardo Christiani, What is the History of Emotions? (Oxford: Polity, 2018), 19-25; Lisa Feldman Barrett, How Emotions are Made: The Secret Life of the Brain (Boston: Mariner Books, 2017), 128-51.

${ }^{10}$ Cf. Paul Ricoeur, who thinks that "experience makes sense through narrative," quoted in Leonard V. Smith, The Embattled Self: French Soldiers' Testimony of the Great War (Ithaca: Cornell University Press, 2007), 17.

${ }^{11}$ For a review of Anglophone historiography of tuberculosis, see Linda Bryder, Flurin Condrau \& Michael Worboys, "Tuberculosis and Its Histories: Then and Now," in Tuberculosis Then and Now: Perspectives on the History of an Infectious Disease, ed. by Flurin Condrau \& Michael Worboys (Montreal: McGill-Queens University Press, 2010), 3-23. Book-length histories of tuberculosis that give room to patient experience include, e.g., Linda Bryder, Below the Magic Mountain: A Social History of Tuberculosis in TwentiethCentury Britain (Oxford: Clarendon Press, 1988); F.B. Smith, The Retreat of Tuberculosis, 1850-1950 (London: Croom Helm, 1988); Katherine Ott, Fevered Lives: Tuberculosis in 
chapter has a contribution to make to the historiography of tuberculosis, thanks above all to the rare source material and the definition of experience outlined above. Medical historians dealing with patient experience have tended to favor its emotional side. While doctors get interrogated primarily with respect to their scientific beliefs and science-based actions, historical studies on patients have tended to focus on their emotional responses, overlooking the fact that patients, too, have beliefs pertaining to the nature and causation of a disease. These beliefs need be neither irrational nor watered-down versions of mainstream medical beliefs. Lay conceptions of disease often have deep cultural roots and can grow into veritable systems of belief. They should be of interest to medical professionals as well, because they clearly matter for patients' treatment choices and compliance.

\section{Stories of Progress}

The ST material revolves around tuberculosis and sanatoria but is not exclusively focused on these. Being long-term beneficiaries of the health care system, the narrators were in a position to witness changes in the social "contract of health," that is, in the development of health-related rights and obligations of citizens and the state, respectively. The collection was carried out at a time when the Finnish welfare state was about to take form. The 1960s had seen waxing criticism of prevailing social, health care, and educational services, and a growing consensus about an urgent need for reform. During the first part of the 1970s, health care and educational services would undergo major reforms, reforms that would bring Finland more closely into line with the other Nordic welfare states. ${ }^{12}$ The

American Culture since 1870 (Cambridge, MA: Harvard University Press, 1996); Sheila M. Rothman, Living in the Shadow of Death: Tuberculosis and the Social Experience of Illness in American History (Baltimore: The Johns Hopkins University Press, 1995); Helen Bynum, Spitting Blood: The History of Tuberculosis (Oxford: Oxford University Press, 2012). Shaw \& Reeves (2009) and Burke (2018) focus on children's sanatorium experiences. In addition, Timothy Boon discusses lay narratives of tuberculosis in the context of health education in "Lay disease narratives, tuberculosis, and health education films," in Tuberculosis Then and Now (2010), 24-48; and Flurin Condrau has used a "hall diary" to investigate patients' selforganization in "Who is the captain of all these men of death? The social structure of tuberculosis sanatorium patients in postwar Germany," Journal of Interdisciplinary History 32:2 (2001), 243-62.

${ }^{12}$ For a concise English analysis of the development of health care services and individual rights in Finland, see Minna Harjula, "Health Citizenship and Access to Health Services: Finland 1900-2000," Social History of Medicine 29:3 (2016), 573-89. 
views and values of the people who contributed to $S T$ represent an interesting combination of old and new ways of thinking about the respective rights and obligations of public authorities and the citizen in the area of health.

Notwithstanding touches of nostalgia, especially when it comes to describing the traditional sanatorium, ${ }^{13}$ the overall image arising from Sanatorium Tradition is that of progress. The participants generally think that things have changed for the better both for themselves and for the nation, and that both are now better equipped to withstand a health threat like tuberculosis. One author exclaimed, "Do not talk to me about the good old days," and went on to discuss people who had succumbed to the disease for lack of proper care. ${ }^{14}$ For another participant, the main justification for organizing the collection in the first place was its capacity to shed light on progress: "It is good to collect such reminiscences for they show the huge steps forward that tuberculosis work has taken and that patients can now cope with their grave plight much better." 15

Part of the progressivist, even celebratory, tone can no doubt be explained by the nature of the collection and the positions of the participants. The latter were well aware that they were taking part in an anniversary collection and garnished their stories with polite expressions of gratitude and triumphal stock phrases like "life will win!" 16 Many of them had lived with tuberculosis for years, even decades, and been left with permanent physical, mental, or social impairments. Still, they were alive and mostly symptom-free, and able to reflect upon their illness histories from the relative safety provided by effective medication and a serviceable social security network. Most ST narratives veer toward what the medical anthropologist Arthur W. Frank has called "the restitution plot," describing the protagonists' path from health to sickness and back to health again. ${ }^{17}$ A picture based solely on ego-documents (e.g., diaries and letters)

\footnotetext{
${ }^{13}$ By the term "traditional sanatorium," I refer here to tuberculosis sanatoria between 1900 and 1960. Sanatoria did not disappear after 1960, but they shed most of their idiosyncratic features, becoming indistinguishable from other institutions of care.

${ }^{14}$ FLSA, Archive Materials on Traditional and Contemporary Culture, Collection Competition for Sanatorium Tradition (henceforth ST), Ylösmäki 7.

${ }^{15}$ FLSA, ST, Haapiainen 25. On progress, see also Harju 84, Mäki-Petäjä 58.

${ }^{16}$ FLSA, ST, Aitamäki 1017, Bogdanoff 39, Juoperi 14, Honkiniemi 19, Huhtanen 4, Kivimäki 17, Koponen 15, Kuusisto 26, Lahti 26, Leskinen 35, Rautavala 14, CPUM 248.

${ }^{17}$ Frank (2013), 14, 77-80, 83.
} 
written when the illness was still active would no doubt look different: darker and, above all, marked by painful insecurity about the future.

The plot usually starts unfolding when the protagonist realizes that she is ill with tuberculosis. The diagnosis constituted a major "biographical disruption." 18 It shattered the protagonists' plans and prospects, and changed their relationship to their bodies, families, and communities, as well as their position in society at large. It is more difficult to identify a singular point of closure. While some authors ended their stories when the sanatorium door closed behind them, others went on to write at length about their post-institutional treatments, relapses, comorbidities, and impairments. They described their efforts to regain a place in the family, the local community, and the nation. The reincorporation of a discharged sanatorium patient was clearly a process rather than an event, and often a long and arduous process marked by setbacks and frustrations. Work was the central element in this process: patients regained their self-esteem and place in society primarily by becoming productive citizens again and, secondarily, by raising a family with healthy, properly educated children. Many narrators, both men and women, recounted their post-institutional work histories in detail, ending the narrative only when they were able to provide for themselves and their families. ${ }^{19}$

On a more general level, the participants regarded effective medication and functioning systems of social support as the most important signs of progress. Thanks to these, tuberculosis diagnosis was no longer a death sentence, nor did it automatically turn a person into a social outcast. ${ }^{20}$ For the ST narrators, social and medical welfare were two sides of the same coin. Financial problems, loss of social status, and stigmatization were an integral part of the overall burden of the disease and were detrimental to

\footnotetext{
${ }^{18}$ On the concept of biographical disruption, see Michael Bury, "Chronic Illness as Biographical Disruption," Sociology of Health and Illness 4:2 (1982), 167-82. Patients often likened being diagnosed with tuberculosis to having received a death sentence. FLSA, ST, Aitamäki 67, Harju 101, Honkiniemi 4, Jaskari 2, Kanervisto 3, Kuusisto 4. See also Nenola (1986), 15.

${ }^{19}$ FLSA, ST, Aitamäki 43-8, 234-5, Aarnio 20-4, Haapiainen 23-5, Hannula 30-1, Heino 5-7, Jäppinen 3-7, Kanervisto 22-4, Kasurinen 6, Kivilahti 19-21, Koponen 14-15, Korhonen 5-6, Kotilainen 15-18, Kuusisto 25-6, Lahti 19-20, 24, Meilo 12-13, MäkiPetäjä 50-8.

${ }^{20}$ FLSA, ST, Salmu 2, Ijäs 3, Ahokas 1, Harju 53.
} 
health, whereas social welfare "promotes recovery, because the money worries were terrible." 21

The authors fully recognized the pivotal importance of the introduction of effective chemotherapeutic medication. However, "the view from below" that ST provides on this turning point is less straightforward and unproblematic than the view conveyed by standard medical histories. The latter tell us that three effective antituberculosis drugs (streptomycin, para-aminosalicylic acid, isoniazid) came to the market between 1947 and 1951, turning tuberculosis into a curable disease. ST describes a halting process with many problems and insecurities. From the patients' point of view, the whole of the 1950s must be regarded as a transitory period. News of the discovery of streptomycin reached Finnish sanatoria fast and gave rise to high hopes, but these hopes were often disappointed. At first, the problem was availability: the supply of imported pharmaceuticals met only a fraction of the demand. Some patients managed to obtain small amounts on the black market, or from their relatives in the USA, Canada, or Sweden. ${ }^{22}$ But even though availability soon improved, affordability long remained a problem. The drugs, being "frightfully expensive," 23 often remained out of reach for poorer patients. A former patient summed up her feelings: "The medicine cost money, a lot of it, and so I had to look aside when my fellow patients were medicated. Who would have given a loan to a tuberculotic? I was not envious, but I was very bitter."24

While medication was welcome, the science behind it remained opaque to the average patient. Patients often misspelled the names of the drugs and mixed up their indications and side effects. It was the social side of things on which they were the real experts by experience. Some felt that the social and financial plight of the tuberculotic had been overlooked in public discussion, perhaps on purpose..$^{25}$ They discussed financial problems at great length and with much passion. The vast majority of $S T$ authors stemmed from the working or lower middle classes. They were smallholders, farm workers, forest workers, skilled or unskilled urban workers, nurses, primary school teachers, cleaners, salespeople, and clerks. Many victims of tuberculosis did not yet have an occupation when they fell ill,

${ }^{21}$ FLSA, ST, Haapiainen 18-19.

${ }^{22}$ FLSA, ST, Stadius 3-4, Saarinen 5, T. Leskinen 21, "Savimäki” 8, CPUM 78.

${ }^{23}$ FLSA, ST, Närhi 2.

${ }^{24}$ FLSA, ST, Kapiainen 6. On the difficulties involved in buying the medicines, FLSA, ST, Eerola 4, Haapiainen 18, Honkiniemi 9-11, Huvinen 29-30, 32, Kanervisto 4.

${ }^{25}$ FLSA, ST, T. Leskinen 1. 
and the disease deprived them of an education. Few had any financial buffer against prolonged illness. For people like this, the financial burden of a chronic disease like tuberculosis could be devastating. ${ }^{26}$ The overall financial burden consisted of three things: the cost of hospitalization, indirect costs of treatment (e.g., travel costs), and loss of income due to incapacity to work.

Prior to World War II, there were two main forms of public assistance to which a tuberculotic with little or no means could resort: she could apply for a free state-subsidized bed in a sanatorium or turn to municipal poor-relief authorities, who might commit to covering one or sometimes several two-three-month periods in a sanatorium. Both forms of assistance were means-tested, and the latter in particular was heavily stigmatized. Recipients of municipal poor relief, known as people "living off the municipality," formed a special social category within the local community. Being relegated to this group was considered shameful, and it could also curtail one's political rights: up until the 1940s, the recipients of municipal poor relief could lose their right to vote in both local and national elections. ${ }^{27}$ Municipal poor relief was an inadequate, unequal, and stigmatizing form of assistance, and it is no wonder that a great many $S T$ participants talk about it with resentment and a lingering sense of injustice. Some narrators took great pains to stress that, however crushing their difficulties, they had never resorted to municipal poor relief. ${ }^{28}$

In discussing improvements in social welfare (summed up in Table 10.1), ST narrators particularly highlighted steps that separated medical welfare from poor relief. The first of these was the National Pension Act (1937), which secured a small basic income for (some) people unable to work. Although the payments were small and not automatically granted, the pension was discussed without the shame and anger that tended to color references to municipal poor relief, and the first payments were sometimes

\footnotetext{
${ }^{26}$ Finnish historian Maria Lähteenmäki has illustrated, by means of a historical case study focused on a single family, how swiftly and thoroughly tuberculosis could destroy the economic and social position of even a relatively well-to-do peasant family. Maria Lähteenmäki, “Taudin merkitsemä pohjoinen perhe. Tuberkuloosin ehkäisy rahvaan elämäntapojen muokkaajana," in Keulakuvia ja peränpitäjï̈. Vanhan ja uuden ybteiskunnan rajalla, ed. by Riitta Oittinen \& Marjatta Rahikainen (Helsinki: SHS, 2000), 147-62.

${ }^{27}$ Harjula (2016), 8, 11.

${ }^{28}$ FLSA, ST, Aarnio 8, Aitamäki 17, 27, Arvola 4, God 2, Haapiainen 18, Huvinen 29, 31-2, Ijäs 5, Järvinen 1, Keränen 4, Kotilainen 5, T. Leskinen 6, Reiman 3-6, Remes 5, Tikkanen 14, CPUM 215.
} 
Table 10.1 The most important legislative steps taken from the point of view of the medical and social welfare of people with tuberculosis

\begin{tabular}{|c|c|c|}
\hline Year & Law or decree & Main consequences for the tuberculotic \\
\hline 1922 & Poor Law & $\begin{array}{l}\text { Obliges municipalities to assist sick people without } \\
\text { means. }\end{array}$ \\
\hline 1927 & $\begin{array}{l}\text { Tuberculosis Decree } \\
(298 / 1927)\end{array}$ & $\begin{array}{l}\text { Introduces mandatory registration of tuberculotics } \\
\text { (with restrictions). }\end{array}$ \\
\hline 1929 & $\begin{array}{l}\text { Law on State Subsidies for } \\
\text { Tuberculosis Sanatoria, } \\
\text { Mental Hospitals, and } \\
\text { Tuberculosis Control } \\
(269 / 1929)\end{array}$ & $\begin{array}{l}\text { Provides generous state subsidies to municipalities } \\
\text { that join together to found tuberculosis sanatoria; } \\
\text { rapidly leads to the formation of a network of major } \\
\text { public sanatoria known as "folk sanatoria" } \\
\text { (kansanparantolat). }\end{array}$ \\
\hline 1937 & National Pension Act & $\begin{array}{l}\text { Provides a small allowance for people too old or } \\
\text { infirm to work. }\end{array}$ \\
\hline 1944 & $\begin{array}{l}\text { "Public health acts" } \\
(220 / 1944,223 / 1944, \\
224 / 1944)\end{array}$ & $\begin{array}{l}\text { Establish a national network of municipal maternal } \\
\text { and child-care clinics with free services. The clinics } \\
\text { contribute to tuberculosis control through } \\
\text { case-detection, vaccination, and referral to infant } \\
\text { preventoria. }\end{array}$ \\
\hline 1948 & $\begin{array}{l}\text { Tuberculosis Act } \\
(649 / 1948)\end{array}$ & $\begin{array}{l}\text { Puts in place a nation-wide public tuberculosis } \\
\text { service with tuberculosis districts, outpatient clinics } \\
\text { (dispensaries), and central sanatoria, and makes the } \\
\text { services of the outpatient clinics free to end user. }\end{array}$ \\
\hline 1956 & $\begin{array}{l}\text { Public Welfare Act } \\
(116 / 1956)\end{array}$ & $\begin{array}{l}\text { Replaces the } 1922 \text { Poor Law; turns the municipal } \\
\text { support for the hospitalization of the tuberculotic } \\
\text { from a loan into an allowance. }\end{array}$ \\
\hline 1956 & $\begin{array}{l}\text { National Pension Act } \\
(347 / 1956)\end{array}$ & $\begin{array}{l}\text { Changes the pension from savings-account-based to } \\
\text { flat-rate pensions; extends the range of recipients } \\
\text { and raises the payments. }\end{array}$ \\
\hline 1960 & $\begin{array}{l}\text { Tuberculosis Act } \\
(355 / 1960)\end{array}$ & $\begin{array}{l}\text { Makes sanatorium treatment free to the patient from } \\
\text { the start of } 1961 .\end{array}$ \\
\hline 1963 & $\begin{array}{l}\text { Law on Universal Health } \\
\text { Insurance }(364 / 1963)\end{array}$ & $\begin{array}{l}\text { Compensates part of the indirect costs caused by the } \\
\text { treatment of tuberculosis (e.g., travel costs) and loss } \\
\text { of income, takes force at the beginning of } 1964 \text {. }\end{array}$ \\
\hline 1972 & $\begin{array}{l}\text { Primary Health Care Act } \\
(66 / 1972)\end{array}$ & $\begin{array}{l}\text { Creates a nation-wide network of primary health- } \\
\text { care centers that offer low-cost medical services. }\end{array}$ \\
\hline 1986 & Tuberculosis Act revoked & $\begin{array}{l}\text { Dissolves the separate tuberculosis services (districts, } \\
\text { offices, sanatoria), discontinues the tuberculosis } \\
\text { register and integrates the regulations concerning } \\
\text { tuberculosis control into the Contagious Disease Act } \\
(786 / 1986) \text {. }\end{array}$ \\
\hline
\end{tabular}

(continued) 
Table 10.1 (continued)

Silmu 1 (1971), 25; Harjula (2016), 10-12; Minna Harjula, Hoitoonpääsyn hierarkiat. Terveyskansalaisuus ja terveyspalvelut Suomessa 1900-luvulla (Tampere: Tampere University Press, 2015), 212-13, 228-9; R. Ahtokari, Elämä voittaa: Puoli vuosisataa työtä keubkovammaisten hyväksi (Helsinki: Otava, 1991), 45, 190; Sakari Härö, Vuosisata tuberkuloosityötä Suomessa: Suomen tuberkuloosin vastustamisyhdistyksen historia (Helsinki: Suomen tuberkuloosin vastustamisyhdistys, 1992), 207-8; Sakari Härö, Tuberculosis in Finland: Dark Past, Promising Future (Helsinki: Finnish Lung Health Association, 1998), 14; Sirkka Törrönen, Tuberkuloosipiirien liitto 1933-1983 (Tuberkuloosipiirien liitto, 1984), 69; Niilo Pesonen, Terveyden puolesta, sairautta vastaan: Terveyden- ja sairaanhoito Suomessa 1800- ja 1900-luvuilla (Porvoo: WSOY, 1980), 492-3

recalled with a downright sense of wonder. ${ }^{29}$ References to disability allowances are more ambiguous. A series of such allowances were introduced during and after the war, but they seldom benefited people whose infirmities had been caused by pulmonary tuberculosis. Patients recounted failed attempts to obtain a disability allowance and complained that the conditions were so strict that you had to be practically dead in order to be eligible. ${ }^{30}$

The 1956 Public Welfare Act constituted a major improvement, as it turned the municipal support for hospitalization from a loan into an allowance. In other words, the municipality was no longer allowed to reclaim what it had paid toward the costs of hospitalization, a move which considerably reduced the overall financial and psychological burden of the less well-off patient. The statute also reduced disparities between municipalities, as some of them had been more aggressive in reclaiming the hospital fees than others. The 1961 Tuberculosis Act was an even more marked improvement, as it made tuberculosis medication free. Summing up the change, a narrator wrote: "times have changed a lot: things are different from back then, for nowadays even poor people can get treatment when they need it." ${ }^{31}$ Universal health insurance, introduced in 1964, compensated for indirect sickness costs and for lost income. It also signaled a major change in attitude toward medical and social welfare. In the words of the historian Minna Harjula, "health insurance was seen as a social right and it created a new, more equal health citizenship in Finland." 32 ST

${ }^{29}$ FLSA, ST, Ahokas 12, Aitamäki 233, Harju 86-7, Holopainen 14-15, Honkiniemi 9, Ijäs 15, Kuusisto 25, Leskelä 46, Närhi 2, Tikkanen 29-30, CPUM 162.

${ }^{30}$ FLSA, ST, Aitamäki 101, 140, 233, 1010-13, Heikkilä 1.

${ }^{31}$ FLSA, ST, God 1.

${ }^{32}$ Harjula (2015), 212-13. 
narrators, many of whom had struggled for years, if not for decades, with an overwhelming financial burden, could hardly believe how much things had changed: "Free sanatorium treatment and a daily allowance. What a comfort and relief!" 33

\section{STORIES OF WAR}

Another prominent narrative strand relates the patients' illness histories in terms of warfare and represents the patient as an unsung hero in combat with a murderous enemy. Several scholars have discussed the use of military metaphors in conceptualizing disease, and some have also pointed out similarities between war and illness stories. ${ }^{34}$ For instance, Arthur W. Frank has noted that illness narratives overlap with survivor stories, of which war stories are an example. ${ }^{35}$ Alessandro Portelli has detected a "functional analogy" between men's war stories and women's hospital stories. In both cases, Portelli observes, narrators "leave their homes to deal with death," "face the state in its bureaucratic and technological aspects," "deal with hierarchies, machinery, and science," "stand up to the big man," and struggle with the technical language of the military and medicine, respectively. ${ }^{36}$ There are also interesting similarities between sanatorium stories and the stories concerning Finnish frontline soldiers of World War II, as analyzed by the historian Ville Kivimäki. Both evoke a journey to a liminal space between life and death and an environment that is at once organized, disciplined, and (on the experiential level) chaotic. Death and suffering are strongly present; personal courage, endurance, and camaraderie are highlighted; gallows humor is a common coping method; and

${ }^{33}$ FLSA, ST, Tuominen 3. See also Huvinen 32 \& God 1.

${ }^{34}$ A well-known discussion on the use of military metaphors can be found in Susan Sontag, Illness and Metaphor (New York: Farrar, Straus \& Giroux, 1978). Medical anthropologist Emily Martin has shown that war, policing, and the nation-state have provided conceptual models and metaphors for discussing the workings of the immune system. Emily Martin, "Toward an Anthropology of Immunology: The Body as Nation-State," Medical Anthropology Quarterly 4:4 (1990), 410-26; Emily Martin, Flexible Bodies: The Role of Immunity in American Culture from the Days of Polio to the Age of AIDS (Boston: Beacon Press, 1994). See also Deborah Lupton, Medicine as Culture: Illness, Disease and the Body in Western Culture, 2nd ed. (London: Sage, 2003 [1996]), 61-3.

${ }^{35}$ Frank (2013), 69.

${ }^{36}$ Portelli (1997), 8. 
members of one's own affective community are clearly demarcated from nonmembers. ${ }^{37}$

It is not surprising that $S T$ narrators resorted to martial metaphors. The generations that they belonged to had been profoundly affected by World War II (1939-45) and also by the Finnish Civil War (1918). For them, the war narrative was a familiar, readily available means of framing personal experiences, enhancing their worth as citizens, and tapping into a national master narrative. Their manner of thinking and talking about tuberculosis was no doubt also influenced by the vigorous antituberculosis campaign, the idiom of which was stridently nationalistic and militaristic, especially in the 1930s-50s, when it was headed by the powerful, semiofficial Finnish Anti-Tuberculosis Association (FATA). ${ }^{38}$ To give but a few examples, FATA "tuberculosis propaganda" urged the entire population to join the "common front" in "the war against tuberculosis," termed "the national disease." Sanatoria were referred to as "citadels" and "fortresses," the family home as "the first line of fire," ambulatory tuberculosis nurses as "frontline soldiers," and the FATA chairman as "the commander." In the postwar years, mass X-ray examinations and the BCG vaccination were hailed as "our new weapons" in the war against tuberculosis. Throughout the 1960s and 1970s, tuberculosis experts kept reminding people that defenses should not be abandoned or weapons laid down prematurely. ${ }^{39}$

\footnotetext{
${ }^{37}$ Ville Kivimäki, Battled Nerves: Finnish Soldiers' War Experience, Trauma, and Military Psychiatry, 1941-44 (Turku: Åbo Akademi University, 2013), 197-269.

${ }^{38}$ The nationalistic and military language of the Finnish antituberculosis campaign has been discussed in Tiina Hautamäki, Tuberkuloosin ja aidsin kulttuuriset merkitykset (Tampere: Tampere University Press, 2002), 12-13, 114, 119-20, 125, 132-3, 136-7, 146, 220; and Hanna Kuusi, "Keuhkotauti kansallisvaarana: Tuberkuloosin vastaiset strategiat Suomessa vuoteen 1939 asti," unpublished MA thesis (Helsinki: University of Helsinki, 1995), 95-6. I have written about the ways in which the two national antituberculosis organizations participated in nation-formation prior to 1917 in Heini Hakosalo, "A twin grip on 'the national disease': The Finnish anti-tuberculosis associations and their contribution to nationformation (1907-17)," in The Making of Finland: The Era of the Grand Duchy. Special issue of Journal of Finnish Studies 21:1-2 (2018), 208-36.

${ }^{39}$ The examples come from Severi Savonen, "Tuberkuloosipäivänä," Tuberkuloosilehti 2:1 (1926), 1-2, here 2; Severi Savonen, "Tuberkuloositaistelun nykyinen nousukausi Suomessa," Tuberkuloosilehti 3:3 (1927), 161-4, here 164; Gust. Rud. Idman, "Richard Sievers 75-vuotias," Tuberkuloosilehti 3:2 (1927), 51-4, here 54; Severi Savonen, "Tärkeä aloite keuhkotautityön tehostamiseksi," Tuberkuloosilehti 8:1 (1932), 29-38, here 31; Tuberkuloosilehti 8:3 (1932), 124-6, here 124; Tuberkuloosilehti 10:1 (1934), 26-31; Severi Savonen, "Mitä keuhkotautitaistelumme rintamalta nykyhetkellä kuuluu (Radioesitelmä 16.XII.1934)," Tuberkuloosilebti 11:1 (1935), 9-14; Severi Savonen, Uudet aseemme keuh-
} 
Sanatorium slang was replete with military terms. For instance, longterm patients were called "veterans" and nontuberculous outsiders "civilians," the implication being that "lungers" and "civilians" were two different groups with such drastically different experiences that it was hard for them to understand each other ${ }^{40}$ Critical authors could refer to sanatoria as "barracks" and criticize doctors and nurses for behaving like noncommissioned officers toward patients. ${ }^{41}$ Military vocabulary and military manners became even more prominent during World War II, when sanatoria became part of the war effort. The bulk of sanatorium beds were reserved for the army and occupied by injured and ill servicemen. ${ }^{42}$ Male sanatorium physicians wore officers' uniforms under their white coats, army manners and forms of address were adopted, and young frontline soldiers became the new elite stratum of the patient population. ${ }^{43}$

On a personal level, too, patients often discussed their disease histories in terms of war, struggle, and combat. They recounted how they had "fought" and "waged war" against the disease, "gained victories," "suffered defeats," and been part of the "tuberculosis front." 44 A female author mused about the pseudonymous Toivonharju sanatorium where "more than three hundred people - mainly young people - wage their own war against death. For most of them, the war will be long, while those waging a blitzkrieg will usually be defeated." ${ }^{45}$ The young age of the average sanatorium patient added weight to military metaphors. The authors sometimes explicitly related their personal struggle to national military history: "It was the beginning of 1945. The war had just ended, and we had

kotaudin hävittämiseksi (Helsinki: Otava, 1947), 20; Severi Savonen, Tuberkuloosisuojarokotus keubkotaudin hävittäjänä (Helsinki: STVY, 1949), 7; Martti Savilahti, "Calmetterokotuksella on armeijassa saatu kiintoisia tuloksia," Terveydenhoitolehti 58 (1946), 276-7; Ahtokari (1991), 53; Härö (1998), 7; Allan Tïtta, Collegium medicum. Lääkintöhallitus 1878-1991 (Helsinki: Lääkintöhallitus, 2009), 399.

${ }^{40}$ FLSA, ST, Ahokas 19, Arola 17, Kivimäki 15-16, Pehkonen 20, Kautto 80, Kuusisto 23, Salmu 39, "Savimäki" 8, CPUM 99, 461.

${ }^{41}$ FLSA, ST, Aitamäki 127, Harju 51-2, Puttonen 9, "Savimäki” 2, CPUM 180.

${ }^{42}$ According to an estimate, circa 15,000 Finnish servicemen fell ill with tuberculosis during WWII. Härö (1992), 166-7. The number of men whose tuberculosis became manifest during peace-time military service was also considerable, although difficult to define with any precision.

${ }^{43}$ FLSA, ST, Alava 16, Hannula 14, CPUM 201, 228.

${ }^{44}$ FLSA, ST, Siermala 23-5, Virtanen 12, CPUM 461.

${ }^{45}$ FLSA, ST, Alava 16. 
embarked upon our peace-time life, but then my own war against a grim disease began." 46

Several authors claimed or implied that the combatants in the war against tuberculosis had not been given their due in the collective memory and in national narratives. Indeed, the need to commemorate them was cited as a motive for answering the writing call. A woman thus wrote that she had decided to mail in a contribution because she wished to report her fellow patients' "courageous struggle against their overwhelming enemy," 47 and another described her father's 50-year struggle with tuberculosis in much the same terms as war heroes were commemorated. ${ }^{48} \mathrm{~A}$ male patient quoted a letter he had received from a sanatorium doctor:

Perhaps you might write a book some day on 'the forgotten heroes.' The hundreds, even thousands of men and women who have endured suffering and died as heroically as frontline soldiers, who have fought within the walls of the sanatorium. Military and civilian courage have often been combined [in the same person]. Apart from those who succumbed, there are plenty of survivors who have gone through a prolonged baptism by fire $[\ldots] .^{49}$

Construed as a battle, a disease history could become a test of courage and persistence, sometimes also as a vehicle of moral refinement.

\section{STORIES OF BELONGING}

Sanatoria, particularly the large public sanatoria erected in the 1930s, can be regarded as "national" institutions from the outset. ${ }^{50}$ They were major public institutions, owned and administered by municipalities and monitored, and mainly funded, by the state. The staff were public officials, which enhanced their status and authority. Sanatoria represented the state of the art in pulmonary medicine and medical technology, and the buildings in which they were housed were often designed by leading architects. Modern sanatoria were associated with health, development, and modernity. Kirsi Saarikangas, a Finnish historian of art and architecture, has

\footnotetext{
${ }^{46}$ FLSA, ST, Närhi 1.

${ }^{47}$ FLSA, ST, Lehtonen 6.

${ }^{48}$ FLSA, ST, Aimo-Koivisto 45.

${ }^{49}$ FLSA, ST, Onni Nikula to Kaarlo Aitamäki 23 July 1971, quoted in Aitamäki 930.

${ }^{50}$ These sanatoria were first known as "folk sanatoria" (kansanparantola) and, from the beginning of the 1950s, as "central sanatoria" (keskusparantola).
} 
remarked that "Sanatoria, together with sports and new sports buildings, played a central role in the creation of the image of a clean healthy Finland." According to Saarikangas, the sanatorium was "the model institution of the first half of the twentieth century." ${ }^{51}$ There is indeed no doubt that sanatoria were an object of national and civic pride. ${ }^{52}$ Such pride was not unique to Finland, ${ }^{53}$ but, in the Finnish case, sanatoria stood out in a particularly clear and impressive outline against the backdrop of the otherwise relatively poorly developed health infrastructure of the newly independent country (Fig. 10.2).

Mundane nationalism was a feature of sanatorium life. National symbols, for instance the Finnish flag, were often on display, and national and religious celebrations were carefully observed. Patients would not have expected anything else, as the nation-state was a self-evident frame of reference at the time. Moreover, patient subculture, known in Finland as "hall culture," involved a playful recreation of national institutions. The term covers the collective and semi-voluntary forms of patient selforganization and self-discipline that revolved around the "hall" (from the German Liegehalle), the communal balcony used for fresh-air treatment of tuberculosis sufferers. Patients sharing a hall formed a "hall state" with an often humorous and gendered name. The most common form of government being a republic, the "state" had a president and a set of ministers, a constitution, a flag, and a national anthem (Fig. 10.3). A newcomer became "a citizen" in a "hall baptism," and received a "hall name" that was entered into the hall diary or ledger. ${ }^{54}$ In their reminiscences, patients characterize the hall state as "a whole society in miniature" 55 and "a wholesome ordered society." ${ }^{56}$ Hall practices alleviated boredom, eased social tensions, and bolstered communality. It is difficult to say when exactly they became part of sanatorium life or how widespread they were. What

\footnotetext{
${ }^{51}$ Kirsi Saarikangas, Asunnon muodonmuntoksia: Pubtauden estetiikka ja sukupuoli modernissa arkkitehtuurissa (Helsinki: SKS, 2002), 92.

${ }^{52}$ E.g., Savonen (1935), 9.

${ }^{53}$ Michael E. Teller, The Tuberculosis Movement: A Public Health Campaign in the Progressive Era (New York: Greenwood Press, 1988), 82; Michael Worboys, "The sanatorium treatment for consumption in Britain, 1890-1914," Medical Innovations in Historical Perspective, ed. by John V. Pickstone (New York: Palgrave Macmillan, 1992), 47-71, here 53. ${ }^{54}$ FLSA, ST, Aitamäki 331-2, 334, Hannula 17-18, Ijäs 35, Luhtala 15-21, Naskali 7, "Savimäki" 2, 5, Tikkanen 5.

${ }^{55}$ FLSA, ST, Ijäs 22.

${ }^{56}$ FLSA, ST, Jaskari 9, 10.
} 


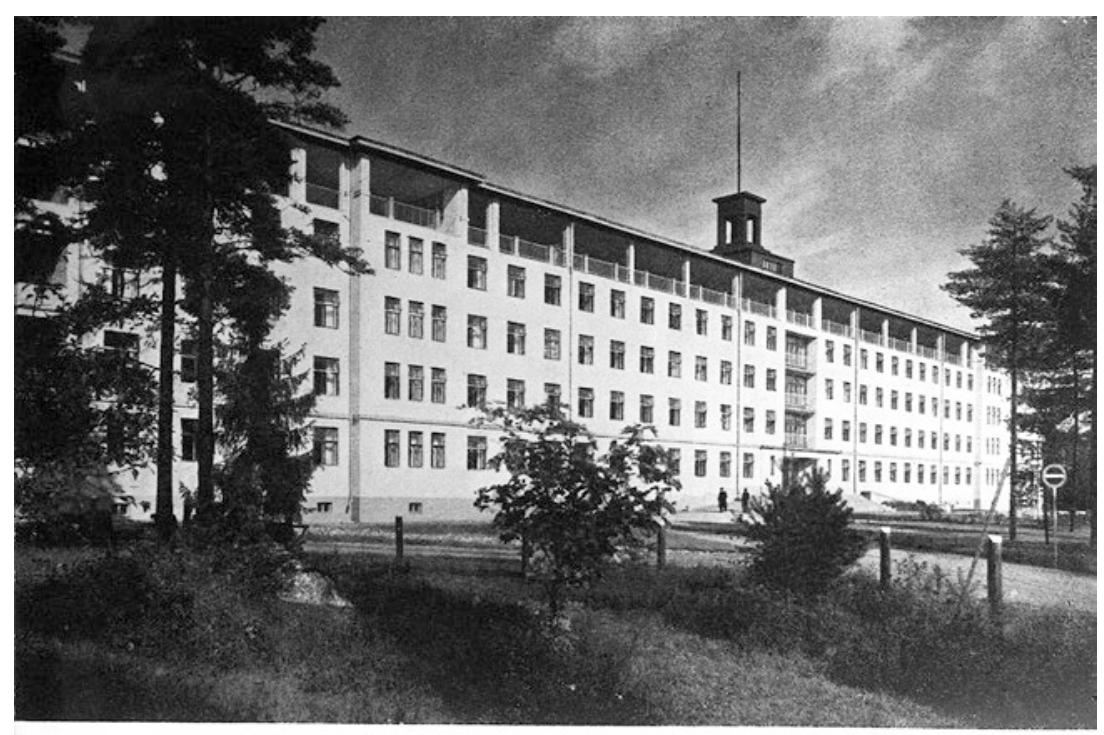

Mjölbollstad Sanatorium.

Fig. 10.2 Mjölbollstad (Meltola) Sanatorium, opened in 1931, was one of the 17 folk sanatoria built between 1925 and 1952. Images like this were displayed in international exhibitions to celebrate Finland's achievements in the field of tuberculosis control and health care. (Photographer unknown. The archive of the Finnish Lung Health Association, Helsinki)

seems clear is that they peaked in the 1930s, waned during and because of World War II, and were replaced by the emergence of formal patient organizations in the 1950s. ${ }^{57}$

$S T$ narrators subjected features of the sanatorium order to harsh criticism. At the same time, they presented it, in some respects, as an ideal institution. They routinely spoke about the sanatorium (community) as a family, household, or home. ${ }^{58}$ A former patient wrote, characteristically,

${ }^{57}$ FLSA, ST, Aitamäki 935. Nenola (1986) is particularly interested in the sanatorium subculture. Again, such sanatorium traditions and rituals were not unique to Finland. See, e.g., Condrau (2001); Rothman (1994), 234.

${ }^{58}$ FLSA, ST, Arola 17, Finnilä 82, Haapiainen 22, Hannula 17, 21, Honkiniemi 17-18, Jänesniemi 15, Jurva 5, Kanervisto 16, Korhonen 11, Kotilainen 10, Natri 2-3, Nevalainen 33, Torvela 5, Wessman 14, Yli-Jyrä 2. 


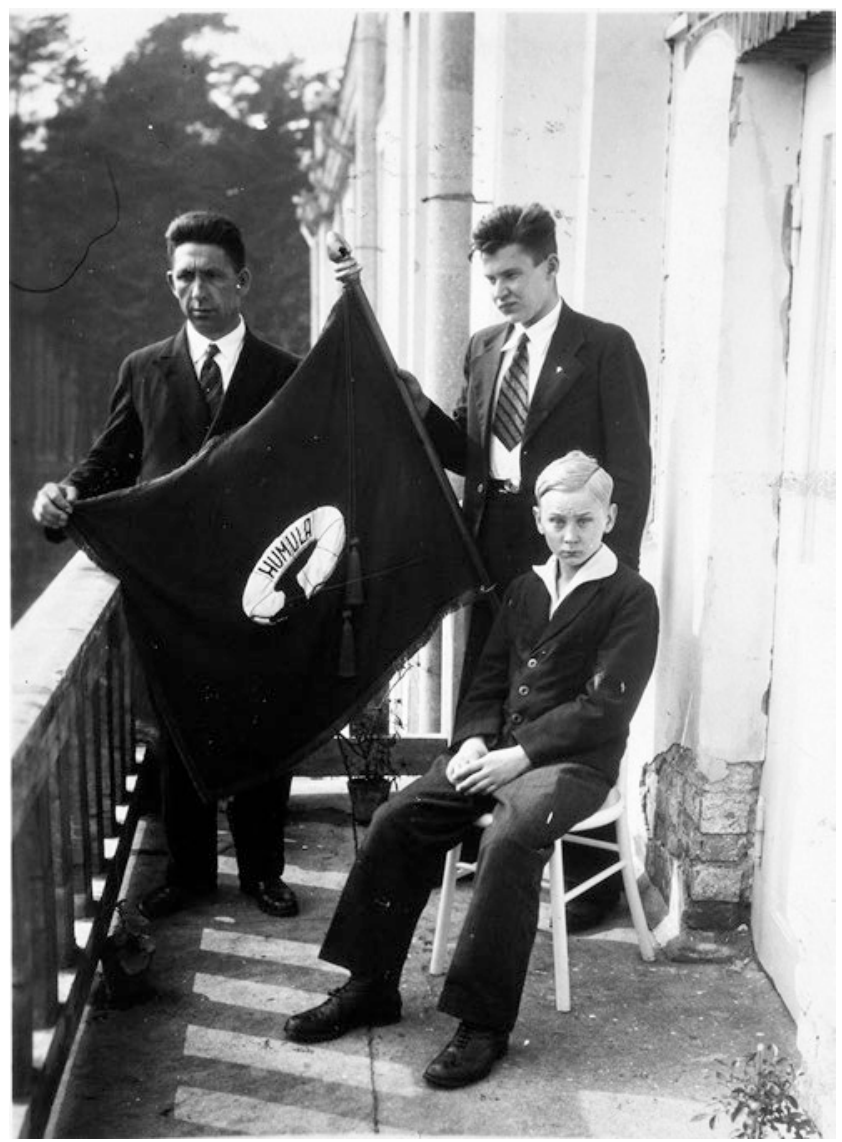

Fig. 10.3 The flag of the Humula hall at Halila Sanatorium. (Photographer unknown. The image archive of the Finnish Literature Society)

that "the sanatorium was like one big family. Someone who hasn't been there, in that society of people who have ended up on the dark side of life, cannot understand this." ${ }^{59}$ An elderly lady with several sanatorium stays behind her wrote that "the sanatorium has been a second home to which I have been able to return whenever the struggle to make a living has

${ }^{59}$ FLSA, ST, Haapianen 21-2. 
surpassed my strength." ${ }^{60}$ This institutional home comes across as patriarchal, hierarchical, and disciplined, but also as caring, harmonious, communal, and, perhaps most surprisingly, equal.

The traditional sanatorium was a rigidly hierarchical institution, with the physician-in-chief at the apex. Patients referred to the latter in their reminiscences as "God," "the supreme God," and "pharaoh." ${ }^{11}$ In sanatorium language, the physician-in-chief was commonly called "superdaddy" and the matron "supermommy." ${ }^{2}$ Indeed, some scholars have been struck by the inferior, even infantile position of the patient within the sanatorium microcosm. ${ }^{63}$ The place of each member of the medical, nursing, and economic staff in the hierarchy was clearly defined. The staff tended to be rank-conscious and adhered to a strict code of address and accessibility. For instance, a former patient recalled that while patients might be on first-name terms with cleaners they never were that with doctors or nurses. ${ }^{64}$ A myriad of written and unwritten rules regulated the patient's life, and some matrons and physicians-in-chief were known as notorious authoritarians. Patients might occasionally rebel against the discipline, but, at least in hindsight, they were prone to judge the discipline as having been necessary and the hierarchy as something that was natural at the time. ${ }^{65}$

The narrators also stressed the harmonious nature of the sanatorium community. Traditional sanatoria took conscious measures to avoid strife, for instance by forbidding religious and political discussions. Some narrators asserted that the latter rule was followed, while others denied this. ${ }^{66}$ Naturally, politics could not be completely excised from the sanatorium. The oldest ST participant, a woman born in 1893 , still treasured the memory of the march that had been organized on the sanatorium grounds to celebrate women's suffrage in $1906 .{ }^{67}$ The collection also contains

${ }^{60}$ FLSA, ST, Finnilä 87.

${ }^{61}$ FLSA, ST, Aitamäki 168, CPUM 189, 200.

${ }^{62}$ The original Finnish "ylipappa" and "ylimamma" are difficult to render in English. Literally, they mean something like "the superior (grand)daddy" and "the superior (grand) mommy." The tone is slightly humorous but not downright irreverent.

${ }^{63}$ Nenola (1986), 35, 120; Bryder (1988), 205.

${ }^{64}$ FLSA, ST, Saarinen 8, CPUM 164.

${ }^{65}$ FLSA, ST, Aitamäki 127, CPUM 180.

${ }^{66}$ FLSA, ST, Aarnio 13, Aitamäki 333, Bogdanoff 33-4, Finnilä 42, Heino 14, Jääskeläinen 32, Jaskari 3-4, Johansson 5, Keränen 3, Kurkinen 2, Mäki-Petäjä 24, Tuominen 111, CPUM 224.

${ }^{67}$ FLSA, ST, Huhtanen 10-11. 
references to other political and social events and developments: the divisive heritage of the Civil War, the Great Depression, the right-wing extremism of the 1930s, the hardships of World War II, the political turmoil of the postwar years, and the 1952 Olympic Games. ${ }^{68}$ Nevertheless, the institution emerged in the ST narratives as a tranquil island sheltered from the worst tempests of national politics. One narrator contrasted the silent, heroic battle being waged in the sanatorium with the mayhem prevailing on the national scene in the 1930s: "Newspapers carried headlines about the [extreme right-wing] Lapua movement, blackshirts and communism. The fatherland was ravaged by the devil. At the same time, real patriots were spitting blood; tuberculosis was really a disease of the people. ${ }^{\circ 9}$

Patients' testimonies as to the equality of the sanatorium community seem inconsistent, even contradictory. Equality among patients receives a lot of praise in ST. "There were no ranks," one author asserted. Others agreed that "Patients were all of equal worth regardless of title and wealth," that "No patient had any special position or privilege," that "age or rank mattered little," and that "We were all just patients whether you yourself paid or [whether your fee was covered by] a municipality or the state." ${ }^{70}$ However, others insisted that the staff treated patients differently, depending on the latter's education, social class, and wealth, ${ }^{71}$ and saw to it that everyone knew who was "living off the municipality" or lagging behind in their monthly payments, something which was "awfully demeaning." 72

External evidence is not altogether conclusive either. It is true that there was relatively little social segregation in Finnish sanatoria. No sanatorium could survive completely without public support, and a sanatorium that received state subsidies had to provide a fixed number of free beds for patients with few means. There were therefore poor patients in private sanatoria, too. Wealthy patients, in turn, sought treatment in folk

${ }^{68}$ FLSA, ST, Aarnio 13, Aitamäki 343, U. Heikkilä 4-5, Honkiniemi 2-3, Ijäs 25 , Tuominen 2, CPUM 196, 232.

${ }^{69}$ FLSA, ST, Meilo 1-2.

${ }^{70}$ FLSA, ST, Hautamäki 10, Järvinen 5, Yli-Jyrä 2, Aarnio 13. See also Huvinen 20, Ijäs 35, Kotilainen 15-16, "Savimäki" 5.

${ }^{71}$ FLSA, ST, Hurskainen 1, Kaario 36, Kairisvuo 2, Walta 3, CPUM 99, 143, 192 , $194,240$.

${ }^{72}$ FLSA, ST, Haapiainen 18-19. For similar statements, see Lindqvist 10, Keränen 3-4, Vesterinen 7. 
sanatoria, because private sanatoria were few and because folk sanatoria represented the state of the art in tuberculosis medicine. There was a degree of spatial segregation in some of the older private sanatoria-rich and poor tended to be housed in different sections of the sanatorium-but the segregation was not particularly strict. ${ }^{73}$ Patients from all classes mingled in the joint dining and day rooms, and private patient rooms and balconies were rare. But education, and especially wealth, mattered. For instance, "work therapy" (cleaning, washing, waiting tables, repairing, or farming) was restricted to public patients. ${ }^{74}$ Specific remedies from cough medicine to phototherapy all cost extra and would therefore be out of poor patients' reach. As long as there were only symptomatic or experimental remedies on offer, this form of inequality was not particularly harmful. However, it became injurious, sometimes even fatal, in the 1950s, when patients were denied effective curative treatment on financial grounds. This did not stop a patient who had been in a sanatorium in the mid-1950s from stating that treatment had been exactly the same for all and that a farmhand "was treated so well that a member of the royal family could not have been better treated." $" 75$

What accounts for such apparent contradictions? First, there were probably genuine differences between different sanatoria in this respect. In some, the staff worked harder than in others to downplay social and financial differences among the patients. ${ }^{76}$ Second, there were changes over time. On the whole, social class and education mattered more in the $1920 \mathrm{~s}$ than in the 1950s. On the other hand, money, or the lack of it, became more of an issue in the 1950s, when the proliferation of canteens, shows, and films meant that there was more use for cash within sanatoria. ${ }^{77}$ Third, even patients who recognized the existence of differential treatment could still be impressed by the relative equality prevailing in sanatoria. Midtwentieth century Finns would not have expected to be treated exactly the same regardless of social class, wealth, and education, but the fact that all patients ate together, were subjected to the same rules, and received the same basic treatment was enough to make poor people regard the

${ }^{73}$ FLSA, ST, Korhonen-Jolma 2, Lindqvist 9-10, Piikamäki 10-11.

${ }^{74}$ FLSA, ST, Saarinen 14.

${ }^{75}$ FLSA, ST, Aitamäki 117, also 103.

${ }^{76}$ FLSA, ST, Jaskari $15,18$.

${ }^{77}$ FLSA, ST, Huhdanmäki 7, Huvinen 31, Jaskari 18, Kairisvuo 1-2, T. Leskinen 17, Luhtala 7, Mäki-Petäjä 19-20, Nyström 1, Reiman 12, Soini 14-15, CPUM 81, 189, 238; "Nytt från förbundet/Sanatorieminnen," Silmu 1 (1971), 28-30, here 30. 
sanatorium as an island of equality. This sentiment was expressed by a woman recounting the story of her stepsister Maria. In the sanatorium, Maria could, for the first time in her life, rest from hard physical work and get enough to eat. "There she felt similar to other people."

"Felt" is the key word here. Many ST narrators regarded the sanatorium as an ideally equal community, despite material evidence to the contrary, because the experience of sharing the same fate was strong enough to override social differences. People suffering from pulmonary tuberculosis shared similar hopes and fears, pains, and limitations. The experience of being feared and rejected by "civilians" was all but universal among patients. Comparisons with leprosy and the plague were common. ${ }^{79}$ In writing about their first admission to a sanatorium, the narrators often evoked their deep sense of relief about being among their own kind and no longer being shunned because of their disease. Even a fellow patient who was not relatable in other respects was a kohtalotoveri, literally, "a comrade in fate." $"{ }^{80}$ It is this sense of shared fate that makes one narrator assert that "Never have I experienced such comradeship and sense of community in 'civilian life' as I did there. Only one who has been there knows that." ${ }^{81}$ This sentiment gets repeated in the ST material time and again. ${ }^{82}$

A sense of community and belonging was not just a matter of comfort but also a therapeutic and restorative factor. The narrators' conception of disease was inherently psychosomatic: they believed that emotional states impacted the course of the disease, and that basically anything that helped them maintain a calm and hopeful frame of mind could have therapeutic value. ${ }^{83}$ We can also appreciate the restorative value of the sense of community when we remember the severe damage that the diagnosis often did to social relationships. Many of the victims had been blocked from their workplaces or schools, avoided by neighbors, left by their girl- or boyfriends, and forced to isolate themselves from their family members. They commonly discussed feelings of worthlessness and social isolation. "The

\footnotetext{
${ }^{78}$ FLSA, ST, Jaatinen $1-2$.

${ }^{79}$ FLSA, ST, Aitamäki 21, "Einonen” 121, Kivilahti 16, Mannermaa 2, Mäki-Petäjä 15-16, Poijärvi 20, Saarikoski 1.

${ }^{80}$ FLSA, ST, Jaskari 8, Huhdanmäki 7, Karapuu 2, Keskinen 3, Lindqvist 10, H. Oksanen 4.

${ }^{81}$ FLSA, ST, Arola 17.

${ }^{82}$ FLSA, ST, Aromaa 17, Kuusisto 23, Kotilainen 15-16, “Mattinen” 130, Saarinen 7, CPUM 193.

${ }^{83}$ FLSA, ST, Aitamäki 37, 59, 62, 65, 72, 103, 104, 171, 928, Avola 34-5, Harju 70, 117 , Jaskari 21, Jänesniemi 12.
} 
tuberculous felt as though cast out of society, as if their lives were over, [that] they were good for nothing, like worn-out pieces of clothing, rags." 84 The intense communality of the sanatorium allowed a patient to remain a social being and thereby limited psychological damage.

In the 1960s, sanatoria became more hospital-like. Patients who had been treated in both the traditional sanatorium and in the 1960s hospitalsanatorium often compared the two. The latter offered more by the way of medical and social services (e.g., the services of an arts and crafts instructor, a physiotherapist, and a social worker), not to mention therapeutic efficiency. It was less isolated and more accessible. The attitude of the staff toward the patients was less authoritarian and formal (even too informal to the taste of some older patients). The outlook of the patient population had also changed drastically. In-patients' average age had risen significantly and they were now more likely to be bed-ridden and wearing hospital pajamas rather than their own clothes. Meals were taken in patient rooms or wards rather than in the communal dining room; joint pastimes had been replaced by television. By the end of the 1960s, the characteristic communality of the sanatorium was gone. As welcome as the new effective services were, patients could also regret the loss of communality and regard the new hospital-sanatorium as a bleak house. ${ }^{85}$

\section{Conclusions}

The view of tuberculosis and sanatoria emerging from patient reminiscences is not quite identical with textbook histories, which are predominantly based on medical publications, administrative documents, and doctors' memoirs. The very conception of illness that informs $S T$ illness narratives is different from the standard biomedical conception. ST narrators made no sharp distinction between somatic, psychological, and social aspects of illness. Rather, they regarded these aspects as entangled and posited multiple causal links between them. Illness, as narrated in ST, was the sum total of many things: physical suffering and reduced function,

\footnotetext{
${ }^{84}$ FLSA, ST, Aitamäki 172. Similarly, a poem called "We," and published in a patient magazine, characterized consumptives as refuse and as mere expenditures for society. Cited in Kasurinen 7-9. See also Finnilä 9, Jaskari 8, Kautto 10.

${ }^{85}$ FLSA, ST, Aitamäki 84, 241-2, 253, 263, 340, 1015, Harju 60-1, 65, 84, Heino 36, Keränen 5, Kotilainen 17, Meilo 7-8, M. Oksanen 25, Salmu 44, Suominen 4, 5-6, Tuominen 3 .
} 
mental anxiety and stress, financial burden, disrupted and frayed social bonds, reduced social status, and social stigma.

Things that alleviated this overall burden of illness counted as progress. Progress could thus encompass medical innovations, but also manifest itself as an investment in public welfare. Stories of personal progression toward better health and wealth became integrated into a national master narrative, that of the emergence of the welfare state. The narrative of war provided another opportunity for the ST narrators to make use of the repository of culturally shared values and concepts and fuse the individual and the national. The third narrative strand singled out in this chapter presented the sanatorium as an ideal nation in miniature, as it were. The authors drew a stark contrast between the harsh prewar society and the traditional sanatorium, which, notwithstanding its many shortcomings, emerged as a place where everyone could count on being cared for, where no one was isolated or disparaged because of tuberculosis, where political and religious strife was kept at bay, and where a sense of community was so strong that it overrode social, linguistic, and religious differences.

Given the average age and the predominantly rural background of the $S T$ participants, the markedly traditional outlook of the ideal sanatorium society does not come as a complete surprise. It is a euphemized reflection of the premodern patriarchal society, with its clear, "natural" (unquestioned) hierarchy, strong leadership, and distinct gender divisions, while also being possessed of close and supportive horizontal relations, consensus, and care. Patients both welcomed the inclusive but impersonal welfare services that accompanied the development of modern Gesellschaft and were nostalgic about the traditional sanatorium Gemeinschaft. This seeming contradiction serves as a reminder that illness narratives are not logical propositions, and do not need to respect either the law of contradiction or the law of the excluded middle. As Arthur W. Frank writes when he speaks about his hospitalization for cancer, "I both hated the hospital and found it was the only place where I felt had a place." 86

Looking at Sanatorium Tradition, one cannot but admire (and, as a researcher, be thankful for) the trouble that the authors went to in putting their reminiscences into words - and also to ponder about their motives for doing so. By way of conclusion, I suggest a twofold motive, a "historical" and a "therapeutic" one. The narrators wanted to witness about their personal ordeal, but also about the historical developments that they had

${ }^{86}$ Frank (2013), 107. 
observed and been part of. In many cases (and some of the narrators say as much), the memory work also served a therapeutic purpose, as it allowed them to take distance from their experiences and create new emotional scenarios. In the last instance, we do not need to see the two motives as separate. The intense sense of vulnerability that accompanied a potentially fatal disease like tuberculosis was easier to own if it could be assigned broader significance and value. By linking their personal illness histories to national history, the narrators could give a sense of purpose and meaning to their losses and suffering. At the same time, their personal testimonies concerning the illness stood as a contribution, however modest, to the national knowledge-community.

Open Access This chapter is licensed under the terms of the Creative Commons Attribution 4.0 International License (http://creativecommons.org/licenses/ by $/ 4.0 /$ ), which permits use, sharing, adaptation, distribution and reproduction in any medium or format, as long as you give appropriate credit to the original author(s) and the source, provide a link to the Creative Commons licence and indicate if changes were made.

The images or other third party material in this chapter are included in the chapter's Creative Commons licence, unless indicated otherwise in a credit line to the material. If material is not included in the chapter's Creative Commons licence and your intended use is not permitted by statutory regulation or exceeds the permitted use, you will need to obtain permission directly from the copyright holder.

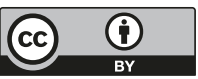

